\title{
DEVELOPING SPEAKING SKILL OF GRADE VIII STUDENTS AT SMP NEGERI 1 PALU THROUGH INTERVIEW
}

\author{
M. Tamrin AM. S. Pettawali \\ Hijrah Syam \\ English Tadris Study Program, Faculty of Tarbiyah and Teacher Training \\ State Institute for Islamic Studies Palu \\ Email: tampettawali99@gmail.com
}

\begin{abstract}
This research aims at developing Speaking Skill through Interview. Its method was quasi-experimental research non-equivalent control group design. Its population was the students of grade VIII at SMP Negeri 1 Palu, in which consists of thirteen parallel classes. The experimental class consists of 29 students and control class consists of 30 students. It was done in eight meetings. The variables of this research were speaking skill and interview. The samples of this research were students of grade VIII C and VIII D, selected through cluster sampling technique. Its results indicate that the application of interview has overcome the students' problem. After analyzing them, the result of t-counted was 10.01 . By applying degree of freedom (df) $57(29+30-2)$, and the level significant 0.05 , the value of t-table was 2.00. So, the value of $t$-counted was higher than $t$-table. It means that the hypothesis of this research was accepted. Thus, the interview can be applied to develop speaking skill of students grade VIII at SMP Negeri 1 Palu.
\end{abstract}

Key words: Developing, Speaking Skill, and Interview 


\section{Introduction}

Language is a communication medium for expressing idea and feeling. In expressing them, we need to speak to send the message to the others. The aim of speaking in a language context is to promote communicative efficiency; teachers want the students actually to be able to use the language as correctly as possible and with a purpose. Students often value speaking more than the other skills of reading, writing and listening. One of the primary benefits of increasing communicative competency is education opportunities. It is always used to communicate with other people. There are still many problems faced by the students and also the problems might be from the teachers themselves who teach monotonously make the students do not have a lot of attention.

Speaking activities can fail miserably due to some very real problems for some students in the classroom. They may also be worried about making mistakes, being criticised and feeling shy in front of the class. A teacher should provide them a proper environment that will help them to develop their speaking skill. The students sometimes have difficulties in expressing their ideas in English. They often feel shy or even scare while attempting to speak and communicate in English. This can obstruct them to make a good progress in their oral ability. The problem is not only found in the beginner, but also at the higher-level students. They can understand English indeed, but when they are asked to speak, they cannot perform it well.

People need to find out a number of words, utter them, know their meaning, and use them in speech acts to converse with others when they want to deliver their purpose. The speaker should know exactly what he wants to speak or communicate. He has to be able to evaluate the effects of his communication to his listener. On the other hands, speaking can be called as oral communication and speaking is one of skills in English learning. This become one important subject that teacher should give. That is why the teachers have big challenge to enable their students to master English well, especially speaking English in class or out of the class.

Students are sometimes hesitate to share their idea because of lack of information that probably might be from their friends in the classroom when they start to get involve into that situation and make conversation with their friends. Speaking is a process to deliver speaker's information or intention during the conversation. The students are expected to feel motivated by various questions that given by others and the questions might be interesting one to have their attention. People communicate to tell their purposes or just want to make a conversation to their partner. The purpose of someone doing communication is to speak or listen to something and he is interested in the communicative purpose of what is being said.

In SMP Negeri 1 Palu, I found that most students are difficult to engage in speaking activity. Besides they said vocalized pause, lack of vocabulary, low confidence, lost idea, not knowing how to pronounce words well, and sometimes obviously being afraid of making mistakes. Some students who spoke English also used inappropriate grammar. Being able to keep speaking English fluently with a native speaker is viewed as the main goal of the students, which underlines as the importance of speaking skill in student's point of view. Therefore, I decide to concentrate on communicative competence in speaking which might be helpful for students to enhance their student's speaking skill by using interview activity.

Interview is one of the best ways to develop students speaking skill. It is a systematic way of talking and listening to people. It is also another way to collect data from individuals through conversations. In 
interviewing people, I use open questions and have to find out or select the appropriate method for addressing the needs of the research question. Thus, I can see facial expression, mimic, gestures of the students closely and know how to control the conversation directly.

\section{Literature Review}

\section{Concept of Speaking}

Generally, speaking skill is the ability to say, to address, to make known, to use or be able to use a given language in the actual communication. Speaking is two people or more interact and function of speaking such as the speaker can express his/her ideas to listener and maintain social relation between speakers with listeners. Brown and Yule (1999: 23) state that there are two primary functions of spoken language: transactional to convey information and interaction to establish and maintain social relation. ${ }^{1}$ It means that interaction occurs when the objects and events naturally influence one to another. Therefore, interactions do not occur only from one side. There must be mutual influence through giving and receiving messages in order to achieve communication. Interaction is also an essential part in teaching and learning process.

Speaking is a process of human being in conveying their ideas to find out and gather information from each other. The following discussion in this research mainly focuses on speaking. According to Nunan (1995: 39), "Speaking is the single most important aspect of learning a second or foreign language, and success is measured in terms of the ability to carry out a

\footnotetext{
${ }^{1}$ Brown. G and Yule, G. 1999. Teaching the Spoken Language : An approach based on the analysis of conversational English. Cambridge : Cambridge University Press.
}

conversation in the language"2. Based on these two definitions, speaking is an interaction between two people or more. Meanwhile, Mead and Rubin (1985) express that speaking is an interactive process in which an individual alternately takes the roles of speaker and listener, and which includes both verbal and nonverbal component $^{3}$. It can be concluded that speaking is an interaction between a speaker and a listener. One obvious example of speaking activity is any interaction between teacher and student. In the interaction, the teacher should have a good speaking competence because he has to bring all of his students to understand the material through his speech. It is in line with Richard (2008: 21) an important dimension of conversation is using a style of speaking that is appropriate to the particular circumstances ${ }^{4}$. Speaking is an important way to convey our idea to others to get some resources that might be needed for someone to extend or enrich his speech in communication. Speaking is just not to get information but it also will be a bridge to help people to be a part of a new community.

\section{Speaking Devices}

There are two kinds of
communicative interaction in
communication process. They are
monologue and dialogue. Wintgens (2013)
states that monologue and dialogue are two
different forms of human communicative

2 Nunan. David. 1995. Language Teaching Methodology. A Textbook for Teachers. London: Phoenix ELT.

${ }^{3}$ Mead. Nancy A and Donal L Rubbin. 1995. Assessing Listening And Speaking Skill. ERIC DIGEST. http://www.ericdigests.org/pre923/speaking.htm. retrieved July 12, 2013.

${ }^{4}$ Richards. Jack C. 2008. Teaching Listening and Speaking. From Theory to Practice. Cambridge. Cambridge University Press. 
interaction ${ }^{5}$. This interaction occurs in our daily activity which has its own function and purpose.

\section{Monologue}

One of the human interaction forms is monologue in which the activity involves a single person only in conveying the idea. Monologue is a personal and participatory speech act, even though only one person may be speaking. We can find out this kind of interaction used in artificial situation e.g. speech, drama and so on. In General, this activity does not demand any response from interlocutor. Wintgens (2013) defines monologue as one-way form of communication between sender and receiver(s) ${ }^{6}$. Furthermore he stated that the roles of participants are precisely defined as sender or receiver of message, without off possibility of exchange. As noted above, monologue commonly does not need any responses from receivers. Most of the ideas come out from the speaker itself.

\section{Dialogue}

Different from monologue which does not demand any responses; a dialogue occurs when there are two or more speakers. In this activity, all participants have the same rights in conveying ideas. Baraldi (2009) states that dialogue is a form of communication in which participants' portions are intentionally questioned and negotiated (second order positioning), in order to reach their positive interactive ${ }^{7}$. According to Huebsch (1986: 173) dialogue is purposeful communication that occurs in a

5 Wintgents. J Luc. 2013. Legislation in Context: Essays in Legisprudence. Belgium: Asthgate Publishing Ltd.

6 Wintgents. J Luc. 2013. Legislation in Context: Essays in Legisprudence. Belgium: Asthgate Publishing Ltd.

${ }^{7}$ Baraldi. Claudio. 2009. Dialogue in Intercultural Communities: From an Educational Point of View. Amsterdam: John Benjamins Publishing Co. structured setting ${ }^{8}$. It means that the communication occurs in two ways communication. Through dialogue people can share what they think and feel to the others by using medium of language.

Sharing information and ideas in two ways communication will be easier to conduct if the participants understand each position. As a result, each participant may speak and respond correctly and appropriately. Moreover, Baraldi (2009) adds that in dialogue the participants' efforts to understand each other and make themselves understood are particularly important ${ }^{9}$. In dialogue, people learn some important features of conversation, such as: greetings, expression, etc. People can practice the dialogue with meaningful and relevant situations of everyday life.

\section{Interview}

Interview is a way to collect data as well as to gain knowledge from individual or group as a part of cooperative learning in speaking class both formally or informally. Since interview is a part of obtaining data and information, it is important that the interview should be understood and set out carefully. Kahn and Cannel (1957) define 'interviewing is a specialized pattern of verbal interaction initiated for a specific purpose, and focused on some specific content areas, with a subsequent elimination of extraneous material' ${ }^{10}$. It means that in interviewing someone, we must direct the question purposefulness and well planned since this activity is emphasized on the aims, goals, and viewpoints of interviewer and interviewee. Interview directs students to enable them to understand vocabulary one

${ }^{8}$ Huesbch. JC. 1986. Communication 2000. Singapore. Butterworth Publisher (Pty) Ltd.

9 Baraldi. Claudio. 2009. Dialogue in Intercultural Communities: From an Educational Point of View. Amsterdam: John Benjamins Publishing Co.

10 Kahn. R.L \& Ch. F. Cannel. 1957. The Dynamics of Interviewing: Theory, Technique and Cases. New York (etc): Wiley. 
by one then they can use it or practice it in the class or outside of the class. This activity can lead students enable to use the language. It also can be valuable to get rid of students' fear of speaking English in front of other students. Interviews are semi-structured sequences of questions intended to elicit particular information and data from the people answering the questions. Typically, one person takes the role of the interviewer and the other people answering the questions. However, with low-level students it can also be worthwhile to have them conduct the interviews in pairs.

\section{Types of Interview}

Interviewing is a technique of gathering data from humans by asking them questions and getting them to react verbally. It is important for the teacher to find out the types of interview before conducting the interview activity in the classroom. It aims at distinguishing which type of interview is appropriated to the student's level. There are a variety of types of interviews that people may conduct. According to Huesbch (1986: 189) types of interviews which may be used to give and receive information, modify beliefs or behavior, and effect changes to systems or whole organizations ${ }^{11}$. They are as follows:

\section{The Employment Interview}

This interview is usually used for the company that wants to seek for their new employee. One of the aims of this employment interview is to discover information about the applicant's attitude, personality, ambitious, motivation and communication abilities. Academic background is also important. This interview is helpful for company for their better future in seeking good human resource before placing them into company.

${ }^{11}$ Huesbch. JC. 1986. Communication 2000. Singapore. Butterworth Publisher (Pty) Ltd.

\section{Counseling Interviews}

This type of interview comes up because of the social problems that lead to the company experiencing problems with employees. Such as, alcohol or drug abuse, excessive stress and strain, too many responsibilities, health hazards, overcrowding (also in the work situation) and intellectual incapacity. The main purpose of this type of interview is the diagnosis of symptoms and the treatment of such symptoms. This is also the case with all other types of interviews, for instance advising students, lecturer-student relations, vocational orientation, employment interviews, placement interviews, and etc.

\section{Grievance Interviews}

This type of interview directed to the power and status differences between employee and supervisor/employer could present serious obstacles to a free and open discussion of grievance. Generally, grievances can be filed for violations of the terms or application of the agreement. Specific items may be precluded from the grievance procedure-for example, performance reviews are a typical exclusion. Arbitration is the final step of the grievance process.

\section{Induction Interviews}

This Induction interviews are informational. Employers conduct induction interviews. For the purpose of explaining specific, operating procedures, and job expectations. Induction interview is also a process of finding, hiring and initiating employees. This is also referred to as full life-cycle recruiting. Most employers create and administer this process to ensure effective and efficient recruiting. This process is also implemented to ensure hiring managers comply with policies, such as affirmative action, equal opportunity employment and non-discrimination. 


\section{Group and Individual Interviews}

The individual is often absorbed in the group. The people present should preferably sit in a circle, and the interviewer should try to arrange the interview in such a way that people of equal social, intellectual and educational levels are brought together. The advantages of the group interview are the following:

- The speaker may get rid of his inhibitions and frustrations by speaking about them and by experiencing the interview's empathy.

- The partcipants in this type of interview may also realise that there are other people who had the same problems as they do. The interviewer may also try to diagnose a few cases simultaneously, especially where symptoms among different people are identical.

\section{Developing Speaking Skill through Interview}

Developing speaking skill is necessary to have clear understanding of the process of speech in an activity. There are many kinds of activities to be implemented in speaking session. One of those activities is interview. Through interview, students may express their feeling, emotion, and react to other students in various situations. Before the interview be applied, the teacher should be able to stimulate students' interest and make them comfortable to share their knowledge and experiences. Richards (2006) states that whether the activities seek to develop proficiency in using talk as interaction transaction or performance, we need to consider what successful completion of the activity involves ${ }^{12}$. Furthermore, the activities deal with the type of criteria we use to assess a speaker's oral performance.

As stated above, varieties of activities in speaking classroom are closely

12 Richards. Jack C. 2006. Developing Classroom Speaking Activities:From Theory to Practice. Guidelines. Vol 28, 2, Dec 2006, pp. 3-9. Singapore:RELC related to the assessment. Richards (2006) points out that speaking activity that requires talk as performance, e.g. a mini lecture, would require different assessment criteria from conversations, group discussions, and speeches ${ }^{13}$. Talk as performance deal with clarity of presentation, use of discourse markers, repetition and stress, while the second activities require different kinds and levels of reparation and support and different criteria obviously had to be used in assessing how well students carry them out.

\section{Teaching Speaking Skill through Interview}

Teaching speaking is a very important part of second language learning. The ability to communicate in a second language clearly and efficiently contributes to the success of the learner in school and success later in every phase of life. River (1968: 244) points out that speaking ability can also be developed in the language club, where students practice communication in an informal atmosphere ${ }^{14}$. It is essential that language teachers should emphasize on teaching speaking skill rather than leading students to pure memorization. Providing a rich environment where meaningful communication takes place is desired. I concludes that the goal of teaching speaking skill is a communicative efficiency i.e. students should try to avoid confusion in the message due to faulty pronunciation, grammar or vocabulary, and to observe the social and cultural rules that apply in each communicative situation.

Teaching speaking is the way for students to express their emotions, communicative needs, interact with other persons in any situation, and influence the others. For this reason, in teaching speaking

13 Richards. Jack C. 2006. Developing Classroom Speaking Activities:From Theory to Practice. Guidelines. Vol 28, 2, Dec 2006, pp. 3-9. Singapore:RELC

${ }^{14}$ Rivers. Wilga. M. 1981. Teaching Foreign Langugae Skill (2nd ed). Chicago: University of Chicago Press. 
skill it is necessary to have clear understanding involved in speech and also encourage the potential of the learners to develop their speaking skill naturally. Hornby (1995: 37) states that teaching means giving the instruction to (a person) give a person (knowledge skill, etc), while speaking means to make use of words in an ordinary voice ${ }^{15}$. So, teaching speaking is ordering or giving instruction to a person to communicate. Therefore, speaking activities in the classroom must be designed in a such way in order to make students complete speaking tasks with fluency. In this case, the teacher takes a very important part in teaching speaking skill which enables students to use the target of language fluently. The teacher should also prepare adequate opportunity to let the students speak because they are expected to be confident in speaking activity. Students are given all necessary steps to be executed as follows; first, the teacher explains the interview and asks some questions related to the interview. Second, the teacher divides students into groups; the groups consist of four or five students in each group. Third, the teacher gives the topic to each group; interview topics may be suggested; introduce someone (Idol, character, hero, admirer, etc), hobbies, family, experiences, favorite food/drink, movies, and life goals. Fourth, teacher monitors and circulates the activity. Fifth, the teacher asks each group to perform in front of class. And the last of the session, the teacher asks students to find out through discussion the "positive essence" of each group.

\section{Learning Speaking Skill through Interview}

Student must involve actively in the learning process particularly in speaking. The teacher should also motivate the student regularly to create a good environment in

15 Hornby. A.S. 1995. Oxford Advanced Learner's Dictionary of Current Language, Oxford: Oxford University Press. the classroom. Rivers (1981: 188) states "teachers persuade themselves that if they speak the new language exclusively in the classroom, they are encouraged to use the language to make students to imitate the way the teacher speaks"16. In other words, students are expected to understand how to use language properly. The language that they are studying should be used to speak or to communicate. Meanwhile, the teacher needs to give more chances or opportunities to the students to practice their speaking skill in the classroom. There are several steps in the learning process of interview. First, the teacher divides the students into several groups. Each group discusses the topic given by the teacher and they determine who will be the interviewer and interviewee. Second, the teacher monitors the groups to practice in their own group before practicing it in the front of class. Third, each group performs in the front of class. Two students in the group serve as the interviewers and the rest as interviewees. Fourth, after having all the answer or information from the interviewee, the interviewer has to reproduce the information from their friends and retell it in front of the class. At the end of the session the group is asked to find through discussion the "positive essence" of each group. For example, self confidence, respect each other, eye contact, gesture and etc.

\section{Research Methodology}

\section{Research Dsign}

This research used quasi experimental non-equivalent control group design. The samples of this research had been divided into two groups. They were experimental group and control group. The pretest and posttest were distributed to both groups.

${ }^{16}$ Rivers. Wilga. M. 1981. Teaching Foreign Langugae Skill (2nd ed). Chicago: University of Chicago Press. 


\section{Population and Sample}

The population of this research was the eighth students of SMP Negeri 1 Palu which consisted of thirteen parallel classes. According to Cresswell (2009: 145), "Population is a group of individuals who had the same charateristics"17. The population were VIII A, VIIIB, VIIIC, VIIID, VIIIE, VIII F, VIII G, VIII H, VIII I, VIII J, VIII K, VIII L, and VIII M.

\section{Variables of the Research}

Variable was known as the conditions that was going to be observed manipulated, or controlled. In this research the variables consisted of two types. They were independent and dependent variables. The independent variable of this research was interview, while the dependent variable was student's speaking skill of the grade VIII students at SMP Negeri 1 Palu.

\section{Instruments of the Research}

There were several research instruments that had been used in this research. The research should have at least one instrument to be conducted. In this research, I had two research instruments. They were observation checklist and test. The test consisted of two kinds, they were pretest and posttest, while the nontest included observation checklist.

\section{Procedure of Data Collection}

Data collection is one of important steps in acquiring data during the research. Pretest had been held before the treatment while posttest had been held after the treatment. It focused on collecting information and data as evidences in answering research question. To collect the data accurately, I used two kinds of techniques. They were observation checklist and test.

17 Cresswell. J. W. 2009. Research Design. Qualitative, Quantitative, and Mixed Methods Approaches. Third Edition. Thousand Oaks, CA: Sage.

\section{Technique of Data Analysis}

The criteria of success had been made to find out the effectiveness of interview. Students were classified success or fail by criteria which presented in the following table: 
Table 1: Scale of Scoring System

\begin{tabular}{|c|l|}
\hline Rating & \multicolumn{1}{|c|}{ Fluency } \\
\hline 5 & $\begin{array}{l}\text { Had to make an effort at time to search for words. Nevertheless, } \\
\text { smooth delivery on the whole and only a few unnatural pauses. }\end{array}$ \\
\hline 4 & $\begin{array}{l}\text { There are not too many unnatural pauses. Fairly smooth delivery } \\
\text { mostly. Occasionally fragmentary but succeeds in conveying the } \\
\text { general meaning. Fair range of expression. }\end{array}$ \\
\hline 3 & $\begin{array}{l}\text { Had to make an effort for much of the time. Often had to search for the } \\
\text { desired meaning. Rather halting delivery and fragmentary. Range of } \\
\text { expression often limited. }\end{array}$ \\
\hline 2 & $\begin{array}{l}\text { Long pauses while he searches for the desired meaning. Frequently } \\
\text { fragmentary and halting delivery. Almost gives up making the effort at } \\
\text { times. Limited range of expression. }\end{array}$ \\
\hline 1 & $\begin{array}{l}\text { Full of long and unnatural pauses. Very halting and fragmentary } \\
\text { delivery. At times gives up making the effort. Very limited range of } \\
\text { expression. }\end{array}$ \\
\hline
\end{tabular}

(Adapted from Heaton, 1988: 100) ${ }^{18}$

${ }^{18}$ Heaton. J. B. 1988.Writing English Language Test. England: Longman Group Limited. 
The Table 1 indicates that scores in each aspect of the assessed speaking skill ranging from $5,4,3,2$, and 1 . The scores were obtained from the individual student oral presentation and converted to use the scale point rating of 100, as follows:

$\begin{array}{llll}\text { Rating } & \text { Score } & \text { Category } & \text { Classification }\end{array}$

Rating 5 equals to 90 - 100 ----------------- Excellent --------------- Successful

Rating 4 equals to 80 - $89 \quad$-------------- Very Good --------------- Successful

Rating 3 equals to 70 - 79 ------------------ Good ------------------- Successful

Rating 2 equals to 60 - 69 ------------------ Fair ------------------ Successful

Rating 1 equals to $50<\quad$----------------- Poor ------------------ Failed

After collecting data through the test, I counted the individual score by using following simple statistic formula proposed by Arikunto (2006: 240) ${ }^{19}$.

$$
\sum=\frac{x}{n} x 100
$$

The data of the research were analyzed by using the simple formula to find out the mean score in the formula proposed by Sugiyono $(2013)^{20}$.

$$
\begin{aligned}
& \overline{\mathbf{X}}_{1}=\frac{\sum \mathbf{X}_{1}}{\mathbf{n}_{1}} \\
& \overline{\mathbf{X}}_{\mathbf{2}}=\frac{\sum \mathbf{X}_{\mathbf{2}}}{\mathbf{n}_{2}}
\end{aligned}
$$

group, I used the formula as proposed by Sugiyono (2013) as follow ${ }^{22}$ :

$$
t=\frac{\overline{x_{1}}-\overline{x_{2}}}{\sqrt{\left(\frac{S S_{1}+S S_{2}}{n_{1}+n_{2}-2}\right)\left(\frac{1}{n_{1}}+\frac{1}{n_{2}}\right)}}
$$

I then compared the result of t-count with the $\mathrm{t}$-table to find out whether $\mathrm{H}_{\mathrm{o}}$ is accepted or rejected. The t-table is found by adjusted df with the formula in significance level $\alpha=$ 5 percent or 0.05 .

\section{FINGDINGS}

\section{Result of Pretest}

The pretest was administered to both

The sum of squared deviation by employing formula proposed by Sugiyono (2013) as follow ${ }^{21}$ :

$$
\frac{\overline{x_{1}}-\overline{x_{2}}}{\sqrt{\left(\frac{S S_{1}+S S_{2}}{n_{1}+n_{2}-2}\right)\left(\frac{1}{n_{1}}+\frac{1}{n_{2}}\right)}} \quad t=
$$

After computing all formula above, I proved the significance between the mean score of posttest in experimental group and control

19 Arikunto. S. 1998. Prosedur Penelitian Suatu Pendekatan Praktis. Jakarta: Binarupa Aksara.

20 Sugiyono. 2013. Metode Penelitian Kuantitatif, Kualitatif. Bandung: Alfabeta.

21 Sugiyono. 2013. Metode Penelitian Kuantitatif, Kualitatif. Bandung: Alfabeta.
22 Sugiyono. 2013. Metode Penelitian Kuantitatif, Kualitatif. Bandung: Alfabeta. 
Table 2: Pretest Score of Experimental Class

\begin{tabular}{|c|c|c|c|c|c|c|c|c|}
\hline \multirow{3}{*}{ Number } & \multirow{3}{*}{$\begin{array}{c}\text { Student's } \\
\text { Initial }\end{array}$} & \multicolumn{5}{|c|}{ Score } & \multirow{3}{*}{ Category } & \multirow{3}{*}{ Classification } \\
\hline & & \multicolumn{2}{|c|}{ Obtained } & \multirow{2}{*}{ Total } & \multirow{2}{*}{ Average } & \multirow{2}{*}{ Standard } & & \\
\hline & & IP & RT & & & & & \\
\hline 1 & $\mathrm{ADL}$ & 7 & 6 & 13 & 6.5 & 43.3 & Poor & Failed \\
\hline 2 & $\mathrm{AF}$ & 5 & 7 & 12 & 6 & 40 & Poor & Failed \\
\hline 3 & AS & 4 & 5 & 9 & 4.5 & 30 & Poor & Failed \\
\hline 4 & $\mathrm{CSY}$ & 5 & 5 & 10 & 5 & 33.3 & Poor & Failed \\
\hline 5 & DAP & 6 & 4 & 10 & 5 & 33.3 & Poor & Failed \\
\hline 6 & DMS & 5 & 7 & 12 & 6 & 40 & Poor & Failed \\
\hline 7 & DPA & 4 & 5 & 9 & 4.5 & 30 & Poor & Failed \\
\hline 8 & DSS & 5 & 4 & 9 & 4.5 & 30 & Poor & Failed \\
\hline 9 & EB & 4 & 3 & 7 & 3.5 & 23.3 & Poor & Failed \\
\hline 10 & FAC & 4 & 4 & 8 & 4 & 26.6 & Poor & Failed \\
\hline 11 & FMK & 3 & 4 & 7 & 3.5 & 23.3 & Poor & Failed \\
\hline 12 & $\mathrm{HB}$ & 5 & 4 & 9 & 4.5 & 30 & Poor & Failed \\
\hline 13 & $\mathrm{HR}$ & 4 & 6 & 10 & 5 & 33.3 & Poor & Failed \\
\hline 14 & HSR & 4 & 5 & 9 & 4.5 & 30 & Poor & Failed \\
\hline 15 & $\mathrm{JH}$ & 6 & 4 & 10 & 5 & 33.3 & Poor & Failed \\
\hline 16 & JI & 5 & 3 & 8 & 4 & 26.6 & Poor & Failed \\
\hline 17 & MTR & 5 & 4 & 9 & 4.5 & 30 & Poor & Failed \\
\hline 18 & NA & 4 & 3 & 7 & 3.5 & 23.3 & Poor & Failed \\
\hline 19 & NAGS & 5 & 5 & 10 & 5 & 33.3 & Poor & Failed \\
\hline 20 & NT & 6 & 6 & 12 & 6 & 40 & Poor & Failed \\
\hline 21 & QAW & 7 & 5 & 12 & 6 & 40 & Poor & Failed \\
\hline 22 & RA & 6 & 4 & 10 & 5 & 33.3 & Poor & Failed \\
\hline 23 & SA & 5 & 5 & 10 & 5 & 33.3 & Poor & Failed \\
\hline 24 & ST & 5 & 7 & 12 & 6 & 40 & Poor & Failed \\
\hline 25 & $\mathrm{TD}$ & 6 & 7 & 13 & 6.5 & 43.3 & Poor & Failed \\
\hline 26 & TDS & 4 & 5 & 9 & 4.5 & 30 & Poor & Failed \\
\hline 27 & WI & 5 & 4 & 9 & 4.5 & 30 & Poor & Failed \\
\hline 28 & $\mathrm{YG}$ & 7 & 7 & 14 & 7 & 46.6 & Poor & Failed \\
\hline 29 & $\mathrm{YN}$ & 4 & 4 & 8 & 4 & 26.6 & Poor & Failed \\
\hline Total & & 145 & 142 & 287 & 143.5 & 956 & & \\
\hline Average & & 5 & 4.89 & 9.89 & 4.948 & 32.96 & Poor & Failed \\
\hline
\end{tabular}

Remarks:

IP: Interview Performance

RT: Report Test

Based on the Table 2, it can be explained that the students got different scores. The standard score is 32.96. It means that the students' achievement in speaking test in the pretest of experimental class was poor. All the students did not perform well in their speaking test. 
Table 3: Pretest Score of Control Class

\begin{tabular}{|c|c|c|c|c|c|c|c|c|}
\hline \multirow{3}{*}{ Number } & \multirow{3}{*}{$\begin{array}{l}\text { Student's } \\
\text { Initial }\end{array}$} & \multicolumn{5}{|c|}{ Score } & \multirow{3}{*}{ Category } & \multirow{3}{*}{ Classification } \\
\hline & & \multicolumn{2}{|c|}{ Obtained } & \multirow[t]{2}{*}{ Total } & \multirow[t]{2}{*}{ Average } & \multirow[t]{2}{*}{ Standard } & & \\
\hline & & IP & RT & & & & & \\
\hline 1 & $\mathrm{AA}$ & 2 & 5 & 7 & 3.5 & 23.3 & Poor & Failed \\
\hline 2 & AAS & 4 & 5 & 9 & 4.5 & 30 & Poor & Failed \\
\hline 3 & $\mathrm{AK}$ & 3 & 4 & 7 & 3.5 & 23.3 & Poor & Failed \\
\hline 4 & AKR & 5 & 5 & 10 & 5 & 33.3 & Poor & Failed \\
\hline 5 & ANW & 4 & 3 & 7 & 3.5 & 23.3 & Poor & Failed \\
\hline 6 & AR & 5 & 6 & 11 & 5.5 & 36.6 & Poor & Failed \\
\hline 7 & DS & 4 & 4 & 8 & 4 & 26.6 & Poor & Failed \\
\hline 8 & EP & 3 & 5 & 8 & 4 & 26.6 & Poor & Failed \\
\hline 9 & FGM & 5 & 4 & 9 & 4.5 & 30 & Poor & Failed \\
\hline 10 & FS & 4 & 6 & 10 & 5 & 33.3 & Poor & Failed \\
\hline 11 & FST & 4 & 5 & 9 & 4.5 & 30 & Poor & Failed \\
\hline 12 & GRA & 5 & 3 & 8 & 4 & 26.6 & Poor & Failed \\
\hline 13 & HA & 5 & 4 & 9 & 4.5 & 30 & Poor & Failed \\
\hline 14 & IAM & 5 & 6 & 11 & 5.5 & 36.6 & Poor & Failed \\
\hline 15 & IGA & 5 & 3 & 8 & 4 & 26.6 & Poor & Failed \\
\hline 16 & INF & 5 & 4 & 9 & 4.5 & 30 & Poor & Failed \\
\hline 17 & IRP & 5 & 5 & 10 & 5 & 33.3 & Poor & Failed \\
\hline 18 & MAW & 6 & 5 & 11 & 5.5 & 36.6 & Poor & Failed \\
\hline 19 & MFM & 7 & 4 & 11 & 5.5 & 36.6 & Poor & Failed \\
\hline 20 & MMAN & 4 & 4 & 8 & 4 & 26.6 & Poor & Failed \\
\hline 21 & MSA & 5 & 4 & 9 & 4.5 & 30 & Poor & Failed \\
\hline 22 & MSC & 4 & 4 & 8 & 4 & 26.6 & Poor & Failed \\
\hline 23 & MWH & 5 & 4 & 9 & 4.5 & 30 & Poor & Failed \\
\hline 24 & NAR & 4 & 3 & 7 & 3.5 & 23.3 & Poor & Failed \\
\hline 25 & NCP & 5 & 6 & 11 & 5.5 & 36.6 & Poor & Failed \\
\hline 26 & NID & 6 & 5 & 11 & 5.5 & 36.6 & Poor & Failed \\
\hline 27 & $\mathrm{NJ}$ & 5 & 3 & 8 & 4 & 26.6 & Poor & Failed \\
\hline 28 & NY & 4 & 3 & 7 & 3.5 & 23.3 & Poor & Failed \\
\hline 29 & RMI & 5 & 5 & 10 & 5 & 33.3 & Poor & Failed \\
\hline 30 & $\mathrm{TN}$ & 4 & 5 & 9 & 4.5 & 30 & Poor & Failed \\
\hline \multicolumn{2}{|l|}{ Total } & 137 & 132 & 269 & 134.5 & 862 & & \\
\hline \multicolumn{2}{|l|}{ Average } & 4.56 & 4.4 & 8.96 & 44.83 & 28.73 & Poor & Failed \\
\hline
\end{tabular}

Remarks:

IP: Interview Performance

RT: Report Test

Related to the findings above, all the students of control class were poor. The highest score is 36.6 while the lowest one is 23.3 .

\section{Result of Posttest}

The result of the posttest from experimental class can be seen below. 
Table 4: Posttest Score of Experimental Class

\begin{tabular}{|c|c|c|c|c|c|c|c|c|}
\hline \multirow{3}{*}{ Number } & \multirow{3}{*}{$\begin{array}{c}\text { Student's } \\
\text { Initial }\end{array}$} & \multicolumn{5}{|c|}{ Score } & \multirow{3}{*}{ Category } & \multirow{3}{*}{ Classification } \\
\hline & & \multicolumn{2}{|c|}{ Obtained } & \multirow{2}{*}{ Total } & \multirow{2}{*}{ Average } & \multirow{2}{*}{ Standard } & & \\
\hline & & IP & RT & & & & & \\
\hline 1 & $\mathrm{ADL}$ & 12 & 10 & 22 & 11 & 73.3 & Good & Successful \\
\hline 2 & $\mathrm{AF}$ & 10 & 13 & 23 & 11.5 & 76.6 & Good & Successful \\
\hline 3 & AS & 10 & 13 & 23 & 11.5 & 76.6 & Good & Successful \\
\hline 4 & CSY & 12 & 13 & 25 & 12.5 & 83.3 & Very Good & Successful \\
\hline 5 & DAP & 12 & 13 & 25 & 12.5 & 83.3 & Very Good & Successful \\
\hline 6 & DMS & 11 & 11 & 22 & 11 & 733 & Good & Successful \\
\hline 7 & DPA & 9 & 12 & 21 & 10.5 & 70 & Good & Successful \\
\hline 8 & DSS & 13 & 10 & 23 & 11.5 & 76.6 & Good & Successful \\
\hline 9 & EB & 11 & 12 & 22 & 11 & 73.3 & Good & Successful \\
\hline 10 & FAC & 10 & 11 & 21 & 10.5 & 70 & Good & Successful \\
\hline 11 & FMK & 9 & 12 & 21 & 10.5 & 70 & Good & Successful \\
\hline 12 & $\mathrm{HB}$ & 11 & 13 & 24 & 12 & 80 & Very Good & Successful \\
\hline 13 & $\mathrm{HR}$ & 10 & 12 & 22 & 11 & 73.3 & Good & Successful \\
\hline 14 & HSR & 12 & 10 & 22 & 11 & 73.3 & Good & Successful \\
\hline 15 & $\mathrm{JH}$ & 12 & 11 & 23 & 11.5 & 76.6 & Good & Successful \\
\hline 16 & JI & 11 & 13 & 24 & 12 & 80 & Very Good & Successful \\
\hline 17 & MTR & 11 & 10 & 21 & 10.5 & 70 & Good & Successful \\
\hline 18 & NA & 11 & 12 & 23 & 11.5 & 76.6 & Good & Successful \\
\hline 19 & NAGS & 12 & 13 & 25 & 12.5 & 83.3 & Very Good & Successful \\
\hline 20 & NT & 11 & 13 & 24 & 12 & 80 & Very Good & Successful \\
\hline 21 & QAW & 12 & 12 & 24 & 12 & 80 & Very Good & Successful \\
\hline 22 & RA & 12 & 11 & 23 & 11.5 & 76.6 & Good & Successful \\
\hline 23 & SA & 12 & 12 & 24 & 12 & 80 & Very Good & Successful \\
\hline 24 & ST & 12 & 13 & 25 & 12.5 & 83.3 & Very Good & Successful \\
\hline 25 & TD & 11 & 11 & 22 & 11 & 73.3 & Good & Successful \\
\hline 26 & TDS & 10 & 12 & 22 & 11 & 73.3 & Good & Successful \\
\hline 27 & WI & 12 & 13 & 25 & 12.5 & 83.3 & Very Good & Successful \\
\hline 28 & YG & 10 & 11 & 21 & 10.5 & 70 & Good & Successful \\
\hline 29 & $\mathrm{YN}$ & 11 & 13 & 24 & 12 & 80 & Very Good & Successful \\
\hline Total & & 322 & 345 & 666 & 333 & 2219.2 & & \\
\hline Average & & 11.10 & 11.96 & 22.96 & 11.48 & 76.52 & Good & Successful \\
\hline
\end{tabular}

Based on the posttest score of experimental activities. Next, the result of control class class, It was found from the Table 4 above can be seen below: that the mean score is 76.52 . It means that, the students were active in speaking 
Table 5: Posttest Score of Control Class

\begin{tabular}{|c|c|c|c|c|c|c|c|c|}
\hline \multirow{3}{*}{ Number } & \multirow{3}{*}{$\begin{array}{l}\text { Student's } \\
\text { Initial }\end{array}$} & \multicolumn{5}{|c|}{ Score } & \multirow{3}{*}{ Category } & \multirow{3}{*}{ Classification } \\
\hline & & \multicolumn{2}{|c|}{ Obtained } & \multirow[t]{2}{*}{ Total } & \multirow[t]{2}{*}{ Average } & \multirow[t]{2}{*}{ Standard } & & \\
\hline & & IP & RT & & & & & \\
\hline 1 & AA & 8 & 6 & 14 & 7 & 46.6 & Poor & Failed \\
\hline 2 & AAS & 6 & 5 & 11 & 5.5 & 36.6 & Poor & Failed \\
\hline 3 & $\mathrm{AK}$ & 5 & 5 & 10 & 5 & 33.3 & Poor & Failed \\
\hline 4 & AKR & 7 & 10 & 17 & 8.5 & 56.6 & Poor & Failed \\
\hline 5 & ANW & 8 & 7 & 15 & 7.5 & 50 & Poor & Failed \\
\hline 6 & $\mathrm{AR}$ & 10 & 9 & 19 & 9.5 & 63.3 & Fair & Successful \\
\hline 7 & DS & 5 & 7 & 12 & 6 & 40 & Poor & Failed \\
\hline 8 & EP & 11 & 8 & 19 & 9.5 & 63.3 & Fair & Successful \\
\hline 9 & FGM & 6 & 10 & 16 & 8 & 53.3 & Poor & Failed \\
\hline 10 & FS & 8 & 11 & 19 & 9.5 & 63.3 & Fair & Successful \\
\hline 11 & FST & 7 & 7 & 14 & 7 & 46.6 & Poor & Failed \\
\hline 12 & GRA & 7 & 7 & 14 & 7 & 46.6 & Poor & Failed \\
\hline 13 & HA & 8 & 8 & 16 & 8 & 53.3 & Poor & Failed \\
\hline 14 & IAM & 7 & 8 & 15 & 7.5 & 50 & Poor & Failed \\
\hline 15 & IGA & 10 & 12 & 22 & 11 & 73.3 & Good & Successful \\
\hline 16 & INF & 11 & 12 & 23 & 11.5 & 76.6 & Good & Successful \\
\hline 17 & IRP & 10 & 6 & 16 & 8 & 53.3 & Poor & Failed \\
\hline 18 & MAW & 8 & 6 & 14 & 7 & 46.6 & Poor & Failed \\
\hline 19 & MFM & 11 & 8 & 19 & 9.5 & 63.3 & Fair & Successful \\
\hline 20 & MMAN & 9 & 5 & 14 & 7 & 46.6 & Poor & Failed \\
\hline 21 & MSA & 6 & 8 & 14 & 7 & 46.6 & Poor & Failed \\
\hline 22 & MSC & 8 & 8 & 16 & 8 & 53.3 & Poor & Failed \\
\hline 23 & MWH & 6 & 10 & 16 & 8 & 53.3 & Poor & Failed \\
\hline 24 & NAR & 8 & 6 & 14 & 7 & 46.6 & Poor & Failed \\
\hline 25 & $\mathrm{NCP}$ & 7 & 6 & 13 & 6.5 & 43.3 & Poor & Failed \\
\hline 26 & NID & 8 & 8 & 16 & 8 & 53.3 & Poor & Failed \\
\hline 27 & NJ & 10 & 8 & 18 & 9 & 60 & Fair & Successful \\
\hline 28 & NY & 7 & 11 & 18 & 9 & 60 & Fair & Successful \\
\hline 29 & RMI & 8 & 8 & 16 & 8 & 53.3 & Poor & Failed \\
\hline 30 & $\mathrm{TN}$ & 7 & 9 & 16 & 8 & 53.3 & Poor & Failed \\
\hline Total & & 237 & 239 & 476 & 238 & 1585 & & \\
\hline Average & & 7.90 & 7.96 & 15.86 & 7.93 & 52.83 & Poor & Failed \\
\hline
\end{tabular}

The mean score of control class posttest is 52.83. The calculation above indicates that the mean score of control class also increase from 28.73 in the pretest and 52.83 in the posttest. But it is not significantly changed like in the experimental class. In the posttest of the control class, there are only some students achieved the criteria of success, and the rest are failed. It was caused by some factors such as less of confident, preparation, and practice. The students still hesitate to deliver their ideas, had long pauses while 
they were searching for the desired meaning, and even sometimes they still almost gave up in making the effort at times. Thus, related to their performance in the posttest, it can be measured that almost all the students are still low in speaking activities.

I calculated every correct item gained by each student in pretest and posttest. In the following Table 5 , the mean scores of pretest and posttest data from both classes are listed with their summary of mean deviation. The interpretation of the table is presented.

Table 6: Descriptive Statistics

\begin{tabular}{lcllllll}
\hline Sample & N & $\begin{array}{l}\text { Mean } \\
\text { Score of } \\
\text { Pretest }\end{array}$ & $\begin{array}{l}\text { Mean } \\
\text { score of } \\
\text { posttest }\end{array}$ & $\begin{array}{l}\text { Mean } \\
\text { Deviation }\end{array}$ & Df & $\begin{array}{c}\text { Sig } \\
\text { level }\end{array}$ & T \\
\hline Experimental & & & & & & & \\
Class & 29 & 32.96 & 76.52 & 43.55 & & & \\
Control Class & 30 & 28.73 & 52.83 & 23 & & & \\
\hline
\end{tabular}

Equal variances assume

The Table 6 represents the summary of statistic data. After the treatment was conducted in experimental class, the mean scores of the pretest developed. The development is clearly seen in mean deviation score from each class. The mean deviation score of experimental class is 43.55 which mean greater than 23 mean deviation of the control class. To test the hypothesis and to make sure the significant different from the data gained, the analysis used was independent sample t-test with degree of freedom 57.

\section{Conclusion}

Speaking skill can be developed through interview. Based on the analysis of pretest result, there are no students of the experimental group get high score. The highest score is achieved only 46 and the lowest one is 23. It indicates that most of the students still get difficulties in speaking skill. While in the posttest of experimental group, it is found that many students make significant progress. There are many students get higher than 60 . The highest score is 86 and the lowest is 70 . It proves that after employing the interview, the students have significant progress in speaking skill. This is also confirmed by the value of $t$-counted (10.01) that is higher than the t-table (2.00). By applying 0.05 level of significance with degree of freedom (df) 57. The result indicates that there is an effect in developing students' speaking skill by teaching interview. Briefly, the alternative hypothesis $\left(\mathrm{H}_{\mathrm{A}}\right)$ was accepted and null hypothesis $\left(\mathrm{H}_{0}\right)$ was rejected.

\section{Suggestion}

English teachers should give more speaking opportunities to the students in various activities. One of the activities that can be applied is interview technique. The teachers are better to speak more English in teaching and learning process in order to make the students more familiar with it. For students, They should encourage to speak English freely and do more participantion in speaking activity. For the next reseacher, they should give special efforts to the students to practice English independently. They are not expected to give monotonous explanation during the teaching and learning process but they should train the students to practice it frequently, since it is an English lesson that is being taught in the classroom. 


\section{References}

Arikunto. S. 1998. Prosedur Penelitian

Suatu Pendekatan Praktis. Jakarta: Binarupa Aksara.

Brown. G and Yule, G. 1999. Teaching the Spoken Language : An approach based on the analysis of conversational English. Cambridge : Cambridge University Press.

Baraldi. Claudio. 2009. Dialogue in Intercultural Communities: From an Educational Point of View. Amsterdam: John Benjamins Publishing Co.

Cresswell. J. W. 2009. Research Design. Qualitative, Quantitative, and Mixed Methods Approaches. Third Edition. Thousand Oaks, CA: Sage.

Kahn. R.L \& Ch. F. Cannel. 1957. The Dynamics of Interviewing: Theory, Technique and Cases. New York (etc): Wiley.

Heaton. J. B. 1988.Writing English Language Test. England: Longman Group Limited.

Hornby. A.S. 1995. Oxford Advanced Learner's Dictionary of Current Language, Oxford: Oxford University Press.

Huesbch. JC. 1986. Communication 2000. Singapore. Butterworth Publisher (Pty) Ltd.

Mead. Nancy A and Donal L Rubbin. 1995. Assessing Listening And Speaking Skill. ERIC DIGEST. hhtp://www.ericdigests.org/pre923/speaking.htm. retrieved July 12, 2013.

Nunan. David. 1995. Language Teaching Methodology. A Textbook for Teachers. London: Phoenix ELT.

Richards. Jack C. 2006. Developing Classroom Speaking Activities:From Theory to Practice. Guidelines. Vol 28, 2, Dec 2006, pp. 3-9. Singapore:RELC

Richards. Jack C. 2008. Teaching Listening and Speaking. From Theory to
Practice. Cambridge. Cambridge University Press.

Rivers. Wilga. M. 1981. Teaching Foreign Langugae Skill (2nd ed). Chicago: University of Chicago Press.

Sugiyono. 2013. Metode Penelitian Kuantitatif, Kualitatif. Bandung: Alfabeta.

Wintgents. J Luc. 2013. Legislation in Context: Essays in Legisprudence. Belgium: Asthgate Publishing Ltd. 